\title{
Treatment for lactation suppression: Little progress in one hundred years
}

\author{
Alison M. Spitz, MS, MPH, ${ }^{a}$ Nancy C. Lee, MD, ${ }^{b}$ and Herbert B. Peterson, MD ${ }^{a}$ \\ Atlanta, Georgia \\ Our goal was to characterize the postpartum symptoms experienced by women who do not breast-feed and \\ to review data on the efficacy of nonpharmacologic methods of lactation suppression. The placebo arms of \\ randomized clinical trials of pharmacologic methods for lactation suppression were used to characterize \\ postpartum symptoms. A subset of the placebo arms was reviewed to assess current strategies for treatment \\ of symptoms associated with lactation suppression. Studies of nonpharmacologic methods of lactation sup- \\ pression were also reviewed to assess efficacy. Engorgement and breast pain may encompass most of the \\ first postpartum week. Up to one third of women who do not breast-feed and who use a brassiere or binder, \\ ice packs, or analgesics may experience severe breast pain. Specific studies of nonpharmacologic methods \\ of lactation suppression were limited and inconclusive. Available data suggest that many women using cur- \\ rently recommended strategies for treatment of symptoms may nevertheless experience engorgement or \\ pain for most of the first postpartum week. (Am J Obstet Gynecol 1998;179:1485-90.)
}

Key words: Lactation, lactation suppression, breast-feeding

In the United States approximately half of women do not breast-feed their newborn infants. ${ }^{1}$ Most of these women choose not to breast-feed, but others may be unable to because of maternal illness, newborn illness or death, or infant adoption. Women may experience considerable pain and engorgement, as well as emotional pain, before lactation cessation occurs, yet the prevalence, duration, and severity of these symptoms are poorly characterized. ${ }^{2}$ From the 1930 s until the late 1980s, pharmacologic methods were used in the United States to suppress lactation. ${ }^{2}$ Since 1988 the US Food and Drug Administration has recommended against the routine use of pharmacologic methods (other than analgesics) for lactation suppression and for relief of associated physical symptoms because evidence from randomized controlled studies on the safety and efficacy of those drugs for that purpose is lacking. ${ }^{3}$

For centuries, physicians and midwives have advised non-breast-feeding mothers to use nonpharmacologic methods to suppress lactation and for relief of accompanying physical symptoms. ${ }^{4}$ From the 16 th through the 19th centuries these techniques included strapping or binding the breasts, emptying the breasts by massage or pump, initiating uterine discharge or bleeding by intrauterine instillation of caustic agents or warm douches,

From the Division of Reproductive Health ${ }^{a}$ and the Division of Cancer Prevention and Control, ${ }^{b}$ National Center for Chronic Disease Prevention and Health Promotion, Centers for Disease Control. Reprint requests: Alison M. Spitz, CDC, 4770 Buford Hwy, Mailstop K35, Atlanta, GA 30341-3724.

$6 / 1 / 92683$ restricting fluids and diet, and applying external products to the breasts and nipples (eg, belladonna ointment). ${ }^{4} 5$ Morphine and codeine were recommended for analgesia when needed. ${ }^{5}$ Twentieth century nonpharmacologic methods of lactation suppression have included strapping or binding the breasts or wearing a tightly fitting brassiere, expressing milk from the breasts mechanically or manually, avoiding milk expression, restricting fluid intake, forcing fluids, and applying external products to the breasts and nipples (eg, ice packs, cabbage leaves, and jasmine flowers) ${ }^{6,7}$

The evolution of recommendations for lactation suppression during the 20th century is exemplified by a review of 19 editions of a standard text (Table I). Use of tight binders was recommended before 1905; by 1908 the recommendation was changed to ice packs and no tight binders. In 1961 tight binders were once again recommended; in 1976 the recommendation for tight binders was changed to one for comfortable binders. Since 1966 mild analgesics have been recommended.

Whereas a range of nonpharmacologic methods has been recommended for lactation suppression, little attention has been given to evaluating the efficacy of these methods. In addition, little is known about the symptoms of women who do not breast-feed. To review these issues, we characterized the symptoms experienced by postpartum women who do not breast-feed and reviewed the data on the efficacy of nonpharmacologic methods of lactation suppression; we have also suggested future research directions for studying the effectiveness of nonpharmacologic methods. Pharmacologic methods have 
Table I. Chronicle of management of lactation suppression as recommended in Williams' Obstetrics*

\begin{tabular}{|c|c|c|}
\hline $\begin{array}{l}\text { Publication } \\
\text { year }\end{array}$ & No. & Management \\
\hline 1903 & 1 & None stated. \\
\hline 1908-1941 & $2-8$ & $\begin{array}{l}\text { Leave breasts alone-Do not express milk, massage breasts, or use tight binder; use ice packs if } \\
\text { necesary; use placebo for pain or, if severe, } 1 \text { dose of morphia; use loose binder for large breasts. } \dagger\end{array}$ \\
\hline 1945 & 9 & $\begin{array}{l}\text { Same as above, plus aspirin and codeine for severe pain. Stilbestrol acknowledged but not } \\
\text { recommended. }\end{array}$ \\
\hline 1950 & 10 & $\begin{array}{l}\text { Same as above plus restrict fluids to a bare minimum; for severe pain, use } 1 \text { grain of codeine and } \\
\text { repeat if necessary. }\end{array}$ \\
\hline 1956 & 11 & Same as above. Hormone therapy acknowledged but not recommended. \\
\hline 1961 & 12 & $\begin{array}{l}\text { Use tight uplift binder and ice packs; limit fluids to a bare minimum; do not pump breasts; use } \\
\text { analgesia for severe pain. }\end{array}$ \\
\hline 1966-1971 & $13-14$ & Same as above plus mild analgesics. \\
\hline 1976 & 15 & Use a comfortable binder, ice packs, and mild analgesics. \\
\hline 1980 & 16 & Same as above. Bromocriptine acknowledged but not recommended. \\
\hline 1985-1989 & $17-18$ & $\begin{array}{l}\text { Same as above. Bromocriptine recommended only after development of severe mammary } \\
\text { engorgement. }\end{array}$ \\
\hline 1993 & 19 & $\begin{array}{l}\text { Same as above. Acknowledged that in } 1988 \text { the US Food and Drug Administration concluded that } \\
\text { no drug should be routinely used to prevent postpartum lactation; acknowledged that several } \\
\text { long-acting parenteral forms of drugs are used to prevent lactation outside of the United States. }\end{array}$ \\
\hline
\end{tabular}

*Complete citations available from the authors on request.

$\nmid$ Recommended management before 1905 included covering breasts with belladonna ointment, bandaging of breasts tightly, pumping "excess" milk from breasts after they became very engorged and painful, and repeating the process as frequently as necessary. ${ }^{5}$

been reviewed in detail elsewhere, ${ }^{2}$ and they are not recommended for use in the United States, so we have focused on nonpharmacologic methods of lactation suppression.

\section{Material and methods}

We searched MEDLINE, Psychological Abstracts, and POPLINE for English language reports on lactation suppression beginning in the years 1965, 1974, and 1970, respectively, through January 1997. For these sources we searched the terms lactation suppression and lactation inhibition appearing anywhere in the article. The Cochrane Pregnancy and Childbirth Database, a database of systematic reviews of published and unpublished controlled trials in pregnancy and childbirth, was also searched for relevant reports for the years 1950 through August 1996. In that database we searched terms appearing anywhere in the title, such as lactation suppression, lactation cessation, lactation stopping, lactation inhibition, stopping lactation, breast engorgement, and drug effects. Finally, we searched the terms lactation prevention and breast-feeding in the Index Catalog for the Library of the Surgeon General's Office, which is a guide to primary sources in medicine and includes more than 3 million books, articles, and pamphlets from the 16th century through the last data set in 1961.

To characterize the symptoms experienced by postpartum women who do not breast-feed, we reviewed data from the placebo arms of pharmacologic studies of lactation suppression. Our criteria for selection were as follows: (1) a randomized trial design, (2) a placebo arm with at least 45 women included, and (3) data on lacta- tion symptoms by either onset, peak days, degree of severity, or use of analgesics for pain. Studies with at least 45 control subjects were chosen to increase the precision of the effect measures. Fourteen studies met these criteria. ${ }^{8-21}$ We also included a study of pharmacologic and nonpharmacologic methods of lactation suppression that met these criteria. ${ }^{7}$ For each of the 15 studies we extracted data on the percentages of women experiencing moderate or severe milk leakage, breast engorgement, and pain and the percentage of women using analgesics for postpartum breast pain.

For our review of studies on nonpharmacologic methods of lactation suppression our criteria for selection were as follows: (1) a clear statement of research question(s) with a focus on measuring the effect of nonpharmacologic methods on lactation suppression; (2) descriptions of the sample, data source, and data collection methods; and (3) data from the United States or another developed country. We identified 5 studies meeting these criteria,7, 22-25 then reviewed and compared the studies on the basis of their study design, treatment groups, data collection method, and results. Two of the 5 studies compared the efficacy of pharmacologic methods; we eliminated these treatment groups for our review.

Finally, to characterize the symptoms experienced by postpartum women who do not breast-feed and who use a brassiere or binder, ice packs, or analgesics (ie, a currently recommended treatment method for lactation suppression), we restricted our review to the data from the placebo arms of the 15 pharmacologic studies of lactation suppression identified here. Eight of these studies included women in the placebo group who used a 
Table II. Symptoms of lactation suppression in postpartum women who do not breast-feed* among placebo groups in clinical trials of pharmacologic lactation suppression methods $\dagger$

\begin{tabular}{|c|c|c|c|}
\hline & Milk leakage & Engorgement & Breast pain \\
\hline \multirow[t]{3}{*}{ Onset } & Days $1-3^{21}$ & Days $1-3^{21}$ & Days $1-3^{21}$ \\
\hline & & Days $2-3^{12}$ & Days 2-312 \\
\hline & & Days $2-4^{7}$ & \\
\hline \multirow[t]{3}{*}{ Peak days } & Days $3-4^{14,17}$; days $3-5^{21}$ & Day $4^{7}$ & Day $3^{7}$ \\
\hline & & Days $3-4^{14,} 17$ & Days $3-4^{14,} 17$ \\
\hline & & Days $3-5^{21}$ & Days $3-5^{21}$ \\
\hline \multicolumn{4}{|c|}{ Degree of severity } \\
\hline Moderate & $22 \%-49 \% 14,15,20$ & $21 \%-66 \% 9,10,13-15,17,18,20$ & $29 \%-68 \% 10,12-17,19,20$ \\
\hline Severe & $17 \%-47 \% 8,11,14,15,20$ & $1 \%-56 \% 7,8,11,14,15,18,20$ & $10 \%$ to $49 \%^{8,10-12,14-16,20}$ \\
\hline \multicolumn{4}{|c|}{ Variability in definitions } \\
\hline Moderate & Mild to moderate ${ }^{15}$ & $\begin{array}{l}\text { Tender and congested, }{ }^{9} \\
\text { firm, } 10,17,18 \text { mild to } \\
\text { moderate, }{ }^{15} \text { or } \\
\text { moderate or severe }{ }^{13}\end{array}$ & $\begin{array}{l}\text { Moderate or severe, } 13 \text { mild to } \\
\text { moderate, }{ }^{15} \text { tender or tender } \\
\text { to palpation, }{ }^{17} \text { painful lactation }{ }^{19}\end{array}$ \\
\hline Severe & & $\begin{array}{l}\text { Hard, painful, reddened } \\
\text { or rock hard }\end{array}$ & \\
\hline
\end{tabular}

\footnotetext{
*Includes studies of women who were instructed to use a brassiere or binder to suppress lactation $7,14-20$; of these, 4 studies included women who were also instructed to use ice packs ${ }^{14-16,18}$ and 7 included women who were also advised to use analgesics for pain. ${ }^{7,14-16,18-20}$ †One study ${ }^{7}$ included pharmacologic and nonpharmacologic methods of lactation suppression.
}

brassiere or binder to suppress lactation ${ }^{7}, 14-20$; of these, 4 included women who were also instructed to use ice packs, ${ }^{14-16,18}$ and 7 included women who were also advised to use analgesics for pain. ${ }^{7,14-16,18-20}$ For the 8 studies we extracted data on the percentages of women in the placebo group who, despite using a brassiere or binder, ice packs, or analgesics, experienced moderate or severe milk leakage, breast engorgement, and pain and the percentage of women who used analgesics for postpartum breast pain. For none of the trials was use of the recommended treatment verified.

Throughout this report, except in Table I, the term brassiere is used when the original reports cited the term tight brassiere, tightly fitting brassiere, supporting brassiere, or supportive brassiere. The term binder is used when the original reports cited the term supporting binder, tight uplift binder, or tight breast binding. Definitions of these terms were given in only 1 of the original reports. ${ }^{24}$

\section{Results}

Symptoms in postpartum women who do not breastfeed. Among women who do not breast-feed, milk leakage and breast pain begin between 1 to 3 days post partum and engorgement begins between 1 and 4 days post partum (Table II). Milk leakage, engorgement, and breast pain peak at 3-5 days post partum. Considerable pain and engorgement can continue after postpartum day $4.7,9,17,19$ In 1 study $29 \%$ and $10 \%$ of women experienced moderate and severe pain, respectively, 14 days post partum. ${ }^{16}$ Between one sixth and one half of women experience moderate or severe milk leakage, and up to two thirds experience moderate or severe engorgement and breast pain (Table II). Use of analgesics for breast pain was reported by $22 \%$ to $47 \%$ of women. $7,8,13,16$
Studies on nonpharmacologic methods of lactation suppression. The results of the 5 studies on nonpharmacologic methods of lactation suppression are varied because of different study designs, treatment groups, and data collection methods. Only 2 studies ${ }^{22,} 24$ reported statistically significant associations between treatment and outcome (Table III). Bristol ${ }^{22}$ found that women who wore "binders" were significantly more likely to report breast pain than those who wore "bras or binders." Brooten et $\mathrm{al}^{24}$ found that women who wore brassieres or binders were significantly more likely to use analgesics than women who had restricted fluid intake. Brooten et $\mathrm{al}^{24}$ also found that women wearing binders were significantly less likely to experience milk leakage than those wearing brassieres or those who had restricted fluid intake. However, these findings are based on small numbers of women.

Symptoms in postpartum women who do not breastfeed and who used a brassiere or binder, ice packs, or analgesics. Among women using a brassiere or binder, ice packs, or analgesics, moderate and severe milk leakage was reported in $22 \%$ to $48 \%$ and $17 \%$ to $40 \%$ of women, respectively. ${ }^{14,15,20}$ Moderate breast engorgement was reported in $21 \%$ to $52 \%$ of women $14,15,17,18,20$ and severe engorgement was reported in $1 \%$ to $44 \%$ of women. $7,11,14,15,18,20$ Moderate pain was reported in $29 \%$ to $68 \%$ of women, ${ }^{7,14-20}$ and severe pain was reported in $10 \%$ to $33 \%$ of women. ${ }^{11}, 14-16,20$ In only 1 study ${ }^{7}$ was the proportion of women using analgesics for pain reported $(42 \%)$.

\section{Comment}

In the United States 2 million women are delivered of live infants each year and do not breast-feed. ${ }^{1}$ Our review 
Table III. Studies on nonpharmacologic lactation suppression methods in postpartum women who do not breast-feed

\begin{tabular}{|c|c|c|c|}
\hline Study & Study design & Treatment group & Age $(y r)$ \\
\hline $\begin{array}{l}\text { Duckman and } \\
\text { Hubbard, }{ }^{7} 1950^{*}\end{array}$ & Prospective & $\begin{array}{l}\text { Group } 1(\mathrm{n}=139): \\
\text { Forced fluids } \\
\quad(2500-5000 \mathrm{~mL} / \mathrm{d}) \\
\text { Group } 2(\mathrm{n}=50): \\
\text { Fluids as usual } \\
(1500-2500 \mathrm{~mL} / \mathrm{d})\end{array}$ & Unknown \\
\hline Bristol,22 1966 & $\begin{array}{l}\text { Prospective, randomized } \\
\text { trials. Exclusion criteria: } \\
\text { Cesarean deliveries or } \\
\text { fever during first } 10 \\
\text { postpartum days }\end{array}$ & $\begin{array}{l}\text { Group } 1(n=19) \text { : } \\
\text { Binder } \\
\text { Group } 2(n=19) \text { : Brassiere } \\
\quad \text { or binder }\end{array}$ & $16-35$ \\
\hline Meserve, ${ }^{23} 1982$ & $\begin{array}{l}\text { Prospective, nonrandomized } \\
\text { trials. Exclusion criteria: } \\
\text { Cesarean deliveries or } \\
\text { multiple births }\end{array}$ & $\begin{array}{l}\text { Group } 1(\mathrm{n}=8) \text { : } \\
\text { Mechanical breast } \\
\text { pumping, brassiere } \\
\text { Group } 2(\mathrm{n}=5) \text { : } \\
\text { Ice packs, } \\
\text { binder, manual } \\
\text { milk expression }\end{array}$ & Unknown \\
\hline Brooten et al, ${ }^{24} 1983^{*}$ & $\begin{array}{l}\text { Prospective, randomized } \\
\text { trials. Exclusion criteria: } \\
\text { Cesarean deliveries, } \\
\text { lacerations, preexisting } \\
\text { medical conditions, or } \\
\text { pregnancy complications }\end{array}$ & $\begin{array}{l}\text { Group } 1(\mathrm{n}=19) \text { : } \\
\text { Brassiere } \\
\text { Group } 2(\mathrm{n}=18): \\
\text { Restricted fluids } \\
\quad\left(1500 \mathrm{~mL} / \mathrm{m}^{2} \text { per day }\right) \\
\text { Group } 3(\mathrm{n}=16): \\
\quad \text { Binder }\end{array}$ & $16-38$ \\
\hline Webster, ${ }^{25} 1986$ & $\begin{array}{l}\text { Prospective, nonrandomized } \\
\text { trials }\end{array}$ & $\begin{array}{l}\text { Group } 1(\mathrm{n}=59) \text { : Manual } \\
\text { or mechanical } \\
\text { breast pumping } \\
\text { (some used binder) } \\
\text { Group } 2(\mathrm{n}=42) \text { : } \\
\text { Brassiere or binder, } \\
\text { fluid restriction, no } \\
\text { breast or nipple } \\
\text { stimulation }\end{array}$ & Unknown \\
\hline
\end{tabular}

*Group that received pharmacologic treatment excluded from these comparisons.

suggests that despite current nonpharmacologic treatment for lactation suppression up to one third of women may experience severe breast pain post partum. Thus each year hundreds of thousands of women may experience moderate or severe symptoms associated with lactation cessation.

In 1752 Smellie 26 reported that “...a turgency commonly begins about the third day; but by rest, moderate sweating, and the use of...applications, the tension and pain will subside about the fifth or sixth day, especially if the milk runs out at the nipples...." Since then, the characterization of the natural progression of lactation cessation in women who do not breast-feed has progressed little. To our knowledge no studies have focused primarily on the symptoms of postpartum women who do not breast-feed. The placebo arms of randomized trials of pharmacologic methods of lactation suppression offered an opportunity to characterize these symptoms, but this method is imperfect because of the different treatment groups, measurement instruments and definitions, and analytic and reporting methods used for each study. Thus future studies of the natural progression of lactation cessation in women who do not breast-feed are needed to more accurately describe the symptoms experienced by these women.

Our review indicates directions for future research. For example, published studies have examined various nonpharmacologic methods that may decrease symptoms in women who do not breast-feed. We suggest future research studies that include treatment groups for (1) wearing a breast binder, (2) wearing a tightly fitting brassiere, (3) pumping breast milk mechanically or manually, (4) applying ice packs to the breasts, (5) applying topical analgesics or other substances to the breasts, and (6) taking only oral analgesics. Careful attention will need to be focused on defining and reliably measuring each of these treatments.

Studies with sufficient sample sizes and appropriate 


\begin{tabular}{|c|c|c|c|}
\hline Parity & Treatment instructions for all women & Data collection method & Results \\
\hline $37 \%$ primiparous & $\begin{array}{l}\text { Use brassiere as needed; } \\
\text { use } 0.032 \mathrm{~g} \text { codeine } \\
\text { with } 0.65 \mathrm{~g} \text { aspirin } \\
\text { as needed }\end{array}$ & $\begin{array}{l}\text { Daily interviews and physical } \\
\text { examination for } 5 \text { days } \\
\text { or up to } 8 \text { days if } \\
\text { still in hospital }\end{array}$ & $\begin{array}{l}\text { Pain, engorgement, } \\
\text { and use of analgesics: } \\
\text { No significant differences } \\
\text { between groups }\end{array}$ \\
\hline Unknown & $\begin{array}{l}\text { Use ice bags if necessary } \\
\text { and aspirin as needed }\end{array}$ & $\begin{array}{l}\text { Daily interviews and physical } \\
\text { examination until discharge; } \\
\text { subsequent interviews on } \\
\text { postpartum days } 5,10 \text {, and } 18\end{array}$ & $\begin{array}{l}\text { Pain: Group } 1 \text { significantly } \\
\text { more than group 2. Milk } \\
\text { leakage, engorgement, } \\
\text { and use of analgesics: } \\
\text { No significant differences } \\
\text { between groups }\end{array}$ \\
\hline Unknown & Unknown & $\begin{array}{l}\text { Self-administered questionnaire } \\
\text { and investigator } \\
\text { measurement } 3 \text { times daily } \\
\text { until engorgement subsided; } \\
\text { telephone interviews at } 2,3 \text {, } \\
\text { and } 4 \text { weeks post partum }\end{array}$ & $\begin{array}{l}\text { Milk leakage, engorgement, } \\
\text { and pain: Group } 1 \text { less } \\
\text { than group } 2\end{array}$ \\
\hline $32 \%$ primiparous & $\begin{array}{l}\text { Wear brassiere; use ice if } \\
\text { necessary and analgesics as } \\
\text { needed; do not stimulate } \\
\text { breasts }\end{array}$ & $\begin{array}{l}\text { Daily interviews and physical } \\
\text { examination on first } 3 \\
\text { postpartum days and on } \\
\text { postpartum day } 5 \text {; subsequent } \\
\text { interviews on postpartum } \\
\text { days } 4,6 \text { or } 7,10 \text {, and } 14\end{array}$ & $\begin{array}{l}\text { Use of analgesics: Groups } 1 \\
\text { and } 3 \text { significantly more } \\
\text { than group } 2 \text {. Milk } \\
\text { leakage: Group } 3 \\
\text { significantly less than } \\
\text { groups } 1 \text { and } 2 \text {. } \\
\text { Engorgement (change in } \\
\text { breast circumference), } \\
\text { incidence and severity of } \\
\text { pain, and use of ice: No } \\
\text { significant differences } \\
\text { between groups }\end{array}$ \\
\hline Unknown & Unknown & $\begin{array}{l}\text { Self-administered questionnaire } \\
3 \text { times daily until 14th } \\
\text { postpartum day }\end{array}$ & $\begin{array}{l}\text { Pain and use of analgesics: } \\
\text { No significant differences } \\
\text { between groups }\end{array}$ \\
\hline
\end{tabular}

power to detect statistically significant differences are needed. In addition, treatment groups should be stratified by parity and previous breast-feeding history because previous childbearing or breast-feeding may affect the natural lactation process. ${ }^{9}$ Although not requisite for valid study results, population-based studies would improve the generalizability of the results.

Future studies should also concentrate on selecting appropriate outcome measures and the means of evaluating them. Not all lactation symptoms may cause discomfort (eg, milk leakage). Other measures (eg, breast pain) are not easily measured objectively, and the study results will depend heavily on the subjective perceptions of the respondents. Researchers will need valid and reliable measurement tools that allow for characterization of outcome measures by onset, duration, prevalence by day, and degree of severity. Observation should extend to at least the first 14 postpartum days, because some symptoms will remain until then. ${ }^{14}$
A review of the studies of women who do not breastfeed and who use a brassiere or binder, ice packs, or analgesics indicates that the nonpharmacologic strategies for lactation suppression that are currently recommended most often may leave a substantial proportion of women in considerable pain for most of the first postpartum week. New research is needed to look at existing and alternative strategies. In the meantime we need to recognize and relieve the pain and discomfort associated with lactation cessation; mild analgesics may be insufficient for many women. In 1909 Storrs,${ }^{5}$ in referring to strategies for management of lactation symptoms at the beginning of the 20th century said that "...a mere list of the suggestions made is bewildering and affords convincing evidence that the vaunted treatment was either inefficacious or useless, or both." One hundred years later, available strategies remain largely unevaluated; existing evidence suggests that current strategies may be inadequate for many women. 
We thank Brenda W. Mazzocchi for assistance with literature searches.

This manuscript was written in memory of Adam A. Garbe.

\section{REFERENCES}

1. Ryan ASW, Rush D, Krieger FW, Lewandowski GE. Recent declines in breast feeding in the U.S., 1984 through 1989. Pediatrics 1991;88:719-27.

2. Parazzini F, Zanaboni F, Liberati A, Tognoni G. Relief of breast symptoms in women who are not breastfeeding. In: Chalmers I, Enkin M, Keirse MJNC, editors. Effective care in pregnancy and childbirth. Oxford: Oxford University Press; 1989. p. 1390-402.

3. US Food and Drug Administration, Fertility and Maternal Health Drugs Advisory Committee. Summary minutes. Prevention of post-partum breast engorgement with sex hormones and bromocriptine. Washington: US Food and Drug Administration; 1989.

4. Fildes VA. Breasts, bottles, and babies. Edinburgh: Edinburgh University Press; 1986.

5. Storrs HJ. Checking the secretion of the lactating breast. Surg Gynecol Obstet 1909;9:401-5.

6. Eaton J. Suppressing lactation. Nurs Times 1991;87:27-30.

7. Duckman S, Hubbard JF. The role of fluids in relieving breast engorgement without the use of hormones. Am J Obstet Gynecol 1950;60:200-4.

8. Billingsley FS. Lactation suppression utilizing norethynodrel with mestranol. J Fla Med Assoc 1956;56:95-7.

9. Hodge C. Relief of pain during suppression of lactation. J Obstet Gynaecol Br Commonw 1969;76:66-8.

10. Iliya FA, Safon L, O'Leary JA. Testosterone enanthate and estradiol valerate for suppression of lactation: a double-blind evaluation. Obstet Gynecol 1966;27:643-5.

11. Lee KH. A trial of chlormezanone, a non-hormonal tranquillizer, for inhibition of postpartum lactation. Aust N Z J Obstet Gynaecol 1971;11:99-102.

12. Louviere RL, Upton RT. Evaluation of deladumone ob in the suppression of postpartum lactation. Am J Obstet Gynecol 1975;121:641-2.

13. MacDonald HN, Collins YD, Tobin MJW, Wijayaratne DN. The failure of pyridoxine in suppression of puerperal lactation. Br J Obstet Gynaecol 1976;83:54-5.

14. Markin KE, Wolst MD. A comparative controlled study of hormones used in the prevention of postpartum breast engorgement and lactation. Am J Obstet Gynecol 1960;80: 128-37.

15. Morris JA, Creasy RK, Hohe PT. Inhibition of puerperal lactation: double-blind comparison of chlorothianesene, testosterone enanthate with estradiol valerate and placebo. Obstet Gynecol 1970;36:107-14.

16. Phillips WP. Prevention of postpartum breast engorgement: double-blind comparison of chlorothianesene $72 \mathrm{mg}$ and placebo. J Ark Med Soc 1975;72:163-7.

17. Schwartz DJ, Palmer EC, Garcia CR, Rickels K, Fisher E. A clinical study of lactation suppression. Obstet Gynecol 1973;42:599-606.

18. Stenchever MA. Evaluation of chlorprophenpyridamine for prevention of postpartum breast engorgement. Am J Obstet Gynecol 1962;840:969-71.

19. Stirrat GM, Anderson GE, Grant O. The effectiveness of stilboestrol in the suppression of postpartum lactation. J Obstet Gynaecol Br Commonw 1968;75:313-5.

20. Primrose T, Tremblay P. Studies on the suppression of lactation by hormones. Am J Obstet Gynecol 1957;73:1218-24.

21. Winter RW, Robinson SC. Prevention of lactation. Obstet Gynecol 1964;23:906-9.

22. Bristol WM. Comparative effectiveness of compressional and supporting breast binders in suppressing lactation. Nurs Res 1966;15:203-6.

23. Meserve Y. Management of postpartum breast engorgement in nonbreastfeeding women by mechanical extraction of milk. J Nurse Midwifery 1982;27:3-8.

24. Brooten D, Brown LP, Hollingsworth AD. A comparison of four treatments to prevent and control breast pain and engorgement in nonnursing mothers. Nurs Res 1983;32:225-9.

25. Webster J. Lactation suppression: a pilot study. Aust J Adv Nurs 1986;4:36-40.

26. Smellie W. A treatise on the theory and practice of midwifery. London: Scolar Press; [1752] 1974. 